\title{
The Influence of Learning Organization, Knowledge Management and Job Satisfaction on Organizational Commitment and Their Impact on Employee Performance of USK Medical Faculty
}

\author{
*Adiansyah, Mukhlis, A. Sakir \\ Management Department, Universitas Syiah Kuala, Indonesia \\ DOI - http://doi.org/10.37502/IJSMR.2021.4515
}

\begin{abstract}
This study intends to examine the effect of learning organizations, knowledge management, and job satisfaction on organizational commitment and their impact on employee performance at the Medical Faculty, Universitas Syiah Kuala (USK Medical Faculty), one of the big universities in Indonesia. The population of this study was all 154 USK Medical Faculty employees. Data were collected using a questionnaire and analyzed using the Structural Equation Modeling (SEM) method. The test results prove that the direct effect testing process proves that there is an effect of organizational learning, knowledge management, and job satisfaction on organizational commitment. In addition, learning organization, job satisfaction, and organizational commitment significantly affect the performance of USK Medical Faculty employees, while knowledge management does not significantly affect USK Medical Faculty employee performance. Furthermore, the results of the indirect effect testing process prove that organizational commitment acts as a full mediator in mediating the influence of knowledge management on the performance of USK Medical Faculty employees, while organizational commitment does not significantly act as a mediator between learning organizational variables and job satisfaction to influence the performance of USK Medical Faculty employees. The interesting thing is it turns out that the model for improving employee performance at USK Medical Faculty depends on the direct influence of learning organizations, job satisfaction, and work commitment. Work commitment turns out to have a role as a full mediation between increasing knowledge management in order to stimulate an increase in the performance of USK Medical Faculty employees.
\end{abstract}

Keywords: Learning Organization, Knowledge Management, Job Satisfaction, Organizational Commitment, Employee Performance. 


\section{Introduction}

The unstoppable development of information technology and economic globalization has given birth to a new millennial era, as a result of the 4.0 industrial revolution. The millennial era in this industrial revolution has demanded every organization to quickly adapt to the times so that the organization still exists and continues to grow in an effort to improve its performance as a modern organization. An organization that wants to keep growing and developing, of course, requires various resources in order to carry out its activities as well as possible.

If an organization cannot change according to the demands of the development of the era in which it is located, then the organization will not compete with other organizations and will even die from the development of the times. For the existence of an organization to continue (continuous), the organization must become a learning organization and continue to improve its knowledge management for every human resource in the organization, so that it has an impact on increasing employee job satisfaction which is feedback from organizational commitment in resource management human power. If this can be realized, of course, it will lead to an increase in employee performance which is one of the key factors or variables determining the success of the organization as a whole.

The Medical Faculty, Universitas Syiah Kuala (USK Medical Faculty), Indonesia, was established on April 1, 1982, based on the Decree of the President of the Republic of Indonesia Number: 16 of 1982 which has the vision to become an excellent, competitive and innovative medical faculty at the national level and global perspective. This institution is a higher education institution within the Public Service Agency (BLU) of Universitas Syiah Kuala. To be able to achieve this vision, all employees are required to be able to understand learning organizations, knowledge management systems so that job satisfaction will encourage increased awareness of their commitment (loyalty) to the organization as a form of motivation to improve their work performance.

Although most of the organization's achievements have shown extraordinary achievements as higher education organizations, if we look at the performance of employees, there are still many improvements and changes that must be made within the USK Medical Faculty. The phenomenon that occurred in USK Medical Faculty from the results of a preliminary study found that employee performance in this organization is still low, as well as organizational commitment owned by employees. Organizational commitment is 3.24 where on the Likert scale unit, these values are still included in the poor category. The lowest value is shown in the indicator of appreciation by the leadership on employee performance which gets the lowest score of 2.83. These low values must receive special attention from all leaders in the USK Medical Faculty environment so that they become the main priority in improvement so that highperformance results and organizational commitment are obtained from each employee.

The low performance shown by USK Medical Faculty employees was also obtained from the results of interviews that the author conducted with students at the faculty. Many students responded that the level of professionalism of each employee is still very low, especially in terms of academic services, where the entire process of student academic needs takes a long time to get 
a solution. The lack of discipline of employees also tarnishes its image for students where during academic service hours it is often found that employees on duty are not on the spot. Sometimes, the emotional level of unstable employees (tends to be quick-tempered) also often has an impact on students who need service which in the end makes these students very uncomfortable.

Apart from the assessment of the administrative staff, the assessment of the educators is also almost similar to the results of the assessment of the administrative staff. But in this case, it is a little different, where to get services from educators makes students quite overwhelmed because it is caused by the busyness of the educators outside the campus. These things seem to have given a red report card to the employee's performance and organizational commitment owned by the employee in the USK Medical Faculty and require immediate treatment from every leader in the USK Medical Faculty.

The low employee performance and organizational commitment of the Medical Faculty employees are caused by many factors, one of which is learning organization factors, knowledge management, and job satisfaction. As expressed by (Hernaus, Bach, \& Vuksic, 2012), Employee performance and organizational commitment have something to do with knowledge management owned by employees, learning organizations provided by the organization to employees, and job satisfaction felt by employees in carrying out their duties and functions.

Learning organizations are closely related to the development of human resources who have high abilities, which greatly support the achievement of the organization's vision and mission to immediately advance and develop rapidly, especially in providing satisfactory services to students as a higher education organization. Ability is a very valuable asset in an organization. Because with the capabilities possessed within an organization internally, it will be able to determine the fate of the organization in the future.

Knowledge is also the organization's most valuable internal resource, unique, difficult to replace, and difficult to imitate. However, many organizations do not know of the hidden knowledge potential of their employees. In addition, job satisfaction is also a major factor in determining employee performance and organizational commitment.

\section{Literature Study}

\section{Employee Performance}

Employee performance greatly determines the performance of an organization as a whole. Referring to the view (Mathis \& Jackson, 2019), the concept of performance stands for kinetics of work energy. The performance which is often referred to as work performance is the result of work in quantity and quality. (Engko, 2008) defines individual performance as individual work performance that is regulated based on standards or criteria that have been set by an organization.

Many factors or variables affect the performance of employees or employees in an organization. As expressed by (Mathis \& Jackson, 2019) there are 3 important factors that affect performance, namely (1) individual ability to do work, (2) effort expended, and (3) organizational support. (Bernardin \& Russell, 2012) stated that employee performance is a 
record of the results of certain work/activities achieved during a certain period. Performance measures include: Output Quality, Output Quantity, Timeliness, Effectiveness, supervision, and interpersonal influence.

In any organization, the activity of evaluating performance is a must. Performance appraisal is the equivalent of performance weighing (Munandar, 2001). (Mathis \& Jackson, 2019) also mentioned that performance measurement can be done using indicators in the form of work quality, work quantity, punctuality, effectiveness, independence, and work commitment.

\section{Organizational Commitment}

(Greenberg \& Baron, 2018) stated that employees who have high organizational commitment are employees who are more stable and more productive so that in the end it will also be more profitable for the organization. In his book (Mowday, Porter, \& Steers, 2013) suggested the characteristics of organizational commitment, namely: (1) a strong belief in and acceptance of the goals and values of the organization; (2) readiness to work hard; and (3) a strong desire to stay in the organization. (Mowday et al., 2013) mentioned a form of work commitment that appears not only passive loyalty but also involves an active relationship with work organizations that have the aim of giving all efforts for the success of the work organization concerned. Measurement of organizational commitment can be done using indicators as disclosed by (Mowday et al., 2013) namely dedication, improving performance, high willingness, and work targets.

\section{Learning Organization}

(Gephart, Marsick, Van Buren, Spiro, \& Senge, 1996) stated that the learning organization is an important element that contributes to achieving organizational performance. Learning organization is based on the basic principles of learning, namely receiving and collecting information, interpreting it, and acting on the interpretation of that information (Basten \& Haamann, 2018). (Pérez López, Manuel Montes Peón, \& José Vazquez Ordás, 2005) mentioned learning organization as a dynamic process of creating, retrieving, and integrating knowledge to develop resources and capabilities in contributing to better organizational performance.

Meanwhile, (Senge, 1990) mentioned learning organizations as organizational skills to create, acquire, interpret, transfer and share knowledge, which aims to modify the behavior of its members to develop new knowledge and insights. Learning organizations can be measured using indicators of system thinking, mental models, personal skills, teamwork, and the ability to share a common vision.

\section{Knowledge Management}

(Davidson \& Voss, 2002) mentioned the management of knowledge management in an organization, namely managing employees and introducing technology so that employees can 
optimize so that they can improve employee performance by communicating with each other. A knowledge management system is a set of technological and social elements that ensure the development of knowledge management processes and the creation of suitable organizational conditions (Matayong \& Mahmood, 2013); (Jønsson, Jain, \& Jeppesen, 2013). This shows that knowledge management is mostly considered as a process involving four basic activities of creating, storing/retrieving, transferring, and applying.

(Ramírez, García-Morales, Morales, \& Martín-Rojas, 2007) said managerial approach aimed at identifying and appraising the knowledge assets of the organization, influencing these assets through knowledge sharing and knowledge creation. Knowledge management can be measured using indicators as expressed by (Ramírez et al., 2007) are (1) closeness of resource persons, (2) improve communication and knowledge sharing with colleagues, (3) improve performance in carrying out tasks (4) encourage me to share things with coworkers, (5) can create value from intellectual assets but also increase productivity, (6) obtain the information they need when they need it.

\section{Job satisfaction}

(Furnham, Petrides, Jackson, \& Cotter, 2002) expressed job satisfaction as a measure of the extent to which individuals are satisfied with the work they do. (Sopiah \& Sangadji, 2018) explained several definitions of job satisfaction, one of which is job satisfaction is a person's emotional response to his work situation and conditions. Emotional responses can be feelings of satisfaction (positive) or dissatisfaction (negative). If emotionally an employee can be satisfied, it means that his satisfaction with his work is achieved and vice versa if not, it means that the employee is not satisfied.

(Sutrisno, 2019) revealed that job satisfaction is an employee's attitude towards work related to his work situation, cooperation between employees, the rewards received in his work, and matters relating to physical and psychological factors. (Koh \& Boo, 2001) mentioned that job satisfaction can be measured using the following indicators, namely compensation, promotion, teamwork, supervision, the work itself.

\section{Conceptual Framework}

The conceptual framework of this research can be described as follows: 


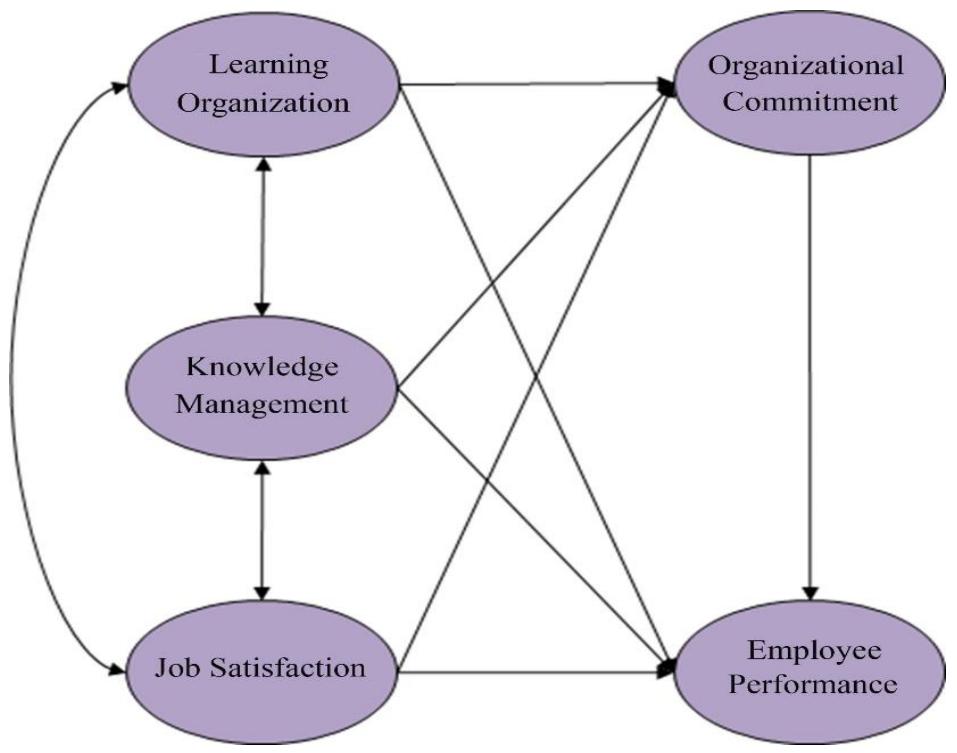

Figure 1. Conceptual Framework

H1 : Learning organization, management knowledge, and job satisfaction at USK Medical Faculty have been going well.

$\mathrm{H} 2$ : organizational commitment significantly influences employee performance at USK Medical Faculty.

H3 : learning organization significantly influences employee performance at USK Medical Faculty.

H4 : knowledge management significantly influences employee performance at USK Medical Faculty.

H5 : job satisfaction significantly influences employee performance at USK Medical Faculty.

H6 : learning organization significantly influences job satisfaction at USK Medical Faculty.

H7 : knowledge management significantly influences job satisfaction at USK Medical Faculty.

H8 : job satisfaction significantly influences job satisfaction at USK Medical Faculty.

H9 : learning organizations significantly influences the performance of USK Medical Faculty employees through organizational commitment

H10: Knowledge management significantly influences employee performance at USK Medical Faculty through organizational commitment.

H11: Job satisfaction significantly influences employee performance at USK Medical Faculty through organizational commitment.

\section{Method}

The location of this research was at the USK Medical Faculty, in Banda Aceh City, Indonesia. The research variables were learning organizations, knowledge management, job satisfaction, organizational commitment, and employee performance. In this study, the population in question was all 154 USK Medical Faculty employees, consisting of 32 civil 
servants (PNS) and 122 contract workers. Sampling was carried out using a census technique on all employees at USK Medical Faculty.

Data were collected using documentation and questionnaires which were measured using a Likert scale. For direct hypothesis testing used the AMOS SEM application. So that mathematically the causal relationship between the constructs in the study can be stated as follows:

$\eta=\gamma 1.1 \xi 1+\gamma 1.2 \xi 2+\gamma 1.3 \xi 3+\zeta 1$

$\eta=\gamma 2.1 \xi 1+\gamma 2.2 \xi 2+\gamma 2.3 \xi 3+\beta 21 \eta 2+\zeta 2$

Or:

Organizational Commitment $=\gamma 11$ knowledge management $+\gamma 12$ learning organization + $\gamma 13$

job satisfaction $+\zeta 1$

Employee Performance $\quad=\quad \gamma 21$ knowledge management $+\gamma 12$ learning organization + $\gamma 13$

$$
\text { job satisfaction }+\beta 21 \text { organizational commitment }+\zeta 2
$$

\section{Result}

Descriptive Hypothesis Testing (H1)

The results of descriptive hypothesis testing are as shown in the following table.

Table 1. Descriptive Hypothesis Test

\begin{tabular}{|c|c|c|c|c|c|c|}
\hline Variable & Average & $\begin{array}{l}\text { Standard } \\
\text { Deviation }\end{array}$ & $\begin{array}{c}\text { Standard } \\
\text { error }\end{array}$ & $\begin{array}{c}\mathrm{t}- \\
\text { count }\end{array}$ & t-table & decision \\
\hline learning organization & 3.960 & 0.819 & 0.066 & 8.483 & 1.655 & H0 rejected \\
\hline knowledge management & 3.885 & 0.896 & 0.072 & 6.719 & 1.655 & $\mathrm{H} 0$ rejected \\
\hline Job satisfaction & 3.826 & 0.954 & 0.077 & 5.541 & 1.655 & $\mathrm{H} 0$ rejected \\
\hline Organizational commitment & 3.891 & 0.906 & 0.073 & 6.728 & 1.655 & $\mathrm{H} 0$ rejected \\
\hline Employee Performance & 3.923 & 0.878 & 0.071 & 7.398 & 1.655 & HO rejected \\
\hline
\end{tabular}

The results of hypothesis testing found that all tests decided to reject the null hypothesis at a significance level of 5\%, which means that all variables in the research model have been running well.

\section{Goodness of Fit}

Before conducting further analysis of this model, a model fit test was conducted with the following results. 
Table 2. Goodness of Fit

\begin{tabular}{|c|c|c|c|}
\hline The goodness of Fit Index & Value & Cut of Value & Decision \\
\hline p-value $x^{2}-$ Chi-Square & 0.418 & $>0.05$ & Closed Fit \\
\hline RMSEA & 0.010 & $\leq 0.08$ & Closed Fit \\
\hline GFI & 0.870 & $\geq 0.90$ & Moderate \\
\hline AGFI & 0.840 & $\geq 0.90$ & Moderate \\
\hline CMJN/DF & 1.015 & $\leq 2.0$ & Closed Fit \\
\hline NNFI & 0.990 & $\geq 0.95$ & Closed Fit \\
\hline CFI & 0.990 & $\geq 0.95$ & Closed Fit \\
\hline
\end{tabular}

Source: Ferdinand, (2012).

The results of the model fit test analysis found that all the criteria were well met so that it can be concluded that this research model fits the data.

\section{Testing the Measurement Model}

The measurement model is a model that explains the relationship between indicators and variables in structural equation modeling. The measurement model includes two important things, namely the first relates to validity and reliability, then the second relates to the priority or level of importance of the indicator in measuring the research variables. An item is said to be valid if it has a loading factor value greater than 0.600 and is said to be reliable if it has composite reliability greater than 0.700 and an Average Variance Extracted (AVE) greater than 0.50 . The results of the measurement model analysis for each variable are described in the subchapter below.

\section{Learning Organization Variable}

The learning organization variable was measured using six items with a path diagram for the measurement model presented in the following figure:

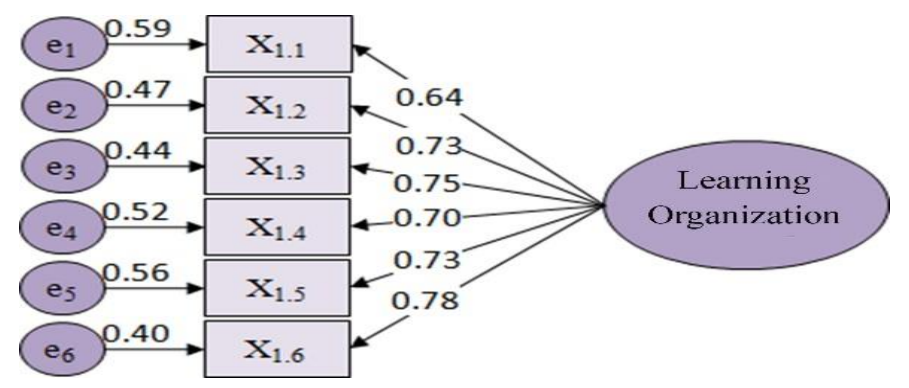

Figure 2. Path Diagram of the Learning Organization 
233 | International Journal of Scientific and Management Research 4(5) 225-244

Table 3. Validity and Reliability of Learning Organization Variable

\begin{tabular}{|l|c|c|c|c|c|}
\hline \multicolumn{2}{|c|}{ Indicator } & $\begin{array}{c}\text { Validity } \\
\text { Coefficient }\end{array}$ & $\mathrm{R} 2$ & $\begin{array}{c}\text { Error } \\
\text { Variance }\end{array}$ & $\begin{array}{c}\mathrm{t}- \\
\text { count }\end{array}$ \\
\hline Think systematically & $\mathrm{X} 1.1$ & 0.640 & 0.410 & 0.590 & - \\
\hline Improve mental models & $\mathrm{X} 1.2$ & 0.730 & 0.533 & 0.467 & 7.51 \\
\hline Improve personal abilities & $\mathrm{X} 1.3$ & 0.750 & 0.563 & 0.438 & 7.90 \\
\hline Increase cooperation in a team & $\mathrm{X} 1.4$ & 0.700 & 0.490 & 0.510 & 7.24 \\
\hline Improve abilities with multiple visions & $\mathrm{X} 1.5$ & 0.730 & 0.533 & 0.467 & 7.54 \\
\hline $\begin{array}{l}\text { Improve the ability to carry out } \\
\text { dialogue }\end{array}$ & $\mathrm{X} 1.6$ & 0.780 & 0.608 & 0.392 & 7.88 \\
\hline Composite Reliability & & \multicolumn{4}{|c|}{0.867} \\
\hline Average Variance Extracted & & & \multicolumn{5}{|c|}{0.523} \\
\hline
\end{tabular}

The results of the analysis for the learning organization variable measurement model found that the item had a loading factor or validity coefficient greater than 0.600 with a t-count value greater than 1.65. These results indicate that all items are valid and significant in measuring the learning organization variable. The most priority or important item in measuring the learning organization variable is the item "increasing the ability to carry out a dialogue" with a loading factor of 0.780 . This can be interpreted that increasing the ability to carry out dialogue according to the majority of USK Medical Faculty employees is a factor that is considered in building a learning organization.

Furthermore, the calculation of composite reliability and AVE gives values of 0.867 and 0.523 , respectively, which can be concluded that all items are not only valid but also reliable in measuring learning organization. The composite reliability value of 0.867 states that $86.7 \%$ of employee evaluations of the learning organization can be reflected in the employee's answers to the six items used to measure this variable. While the AVE of 0.523 stated that $52.3 \%$ of the variations in employee answers to the six items were influenced by their understanding of learning organizations. The higher the composite reliability and AVE values, the more reliable these six items are in measuring learning organizational variables.

\section{Knowledge Management Variable}

The knowledge management variable is measured by six indicators with the path diagram presented as follows:

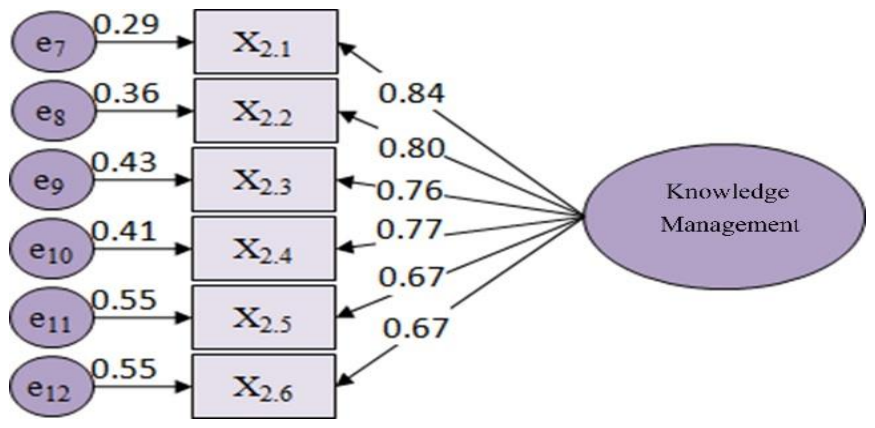


234 | International Journal of Scientific and Management Research 4(5) 225-244

Figure 3. Path Diagram of Knowledge Management

Table 4. Validity and Reliability of Knowledge Management Variable

\begin{tabular}{|l|c|c|c|c|c|}
\hline \multicolumn{2}{|c|}{ Indicator } & $\begin{array}{c}\text { Validity } \\
\text { Coefficient }\end{array}$ & $\mathrm{R} 2$ & $\begin{array}{c}\text { Error } \\
\text { Variance }\end{array}$ & $\begin{array}{c}\mathrm{t} \text { - } \\
\text { count }\end{array}$ \\
\hline $\begin{array}{l}\text { Closeness to other employees and co- } \\
\text { worker satisfaction }\end{array}$ & $\mathrm{X} 2.1$ & 0.840 & 0.706 & 0.294 & - \\
\hline $\begin{array}{l}\text { Improve communication and } \\
\text { knowledge sharing }\end{array}$ & $\mathrm{X} 2.2$ & 0.800 & 0.640 & 0.360 & 11.19 \\
\hline Improve the resulting performance & $\mathrm{X} 2.3$ & 0.760 & 0.578 & 0.422 & 10.58 \\
\hline Encouraging to share things & $\mathrm{X} 2.4$ & 0.770 & 0.593 & 0.407 & 10.60 \\
\hline Increase productivity & $\mathrm{X} 2.5$ & 0.670 & 0.449 & 0.551 & 8.81 \\
\hline Get the required information & $\mathrm{X} 2.6$ & 0.670 & 0.449 & 0.551 & 8.95 \\
\hline Composite Reliability & & & 0.887 & \\
\hline Average Variance Extracted & & \multicolumn{4}{|c|}{0.569} \\
\hline
\end{tabular}

The results of the analysis for the knowledge management variable measurement model found that the item had a loading factor or validity coefficient greater than 0.600 with a t-count value greater than 1.65. These results indicate that all items are valid and significant in measuring knowledge management variables. The most priority or important item in measuring the knowledge management variable is the item Proximity to other employees and the satisfaction of coworkers with a loading factor of 0.840 . This can be interpreted that the closeness to other employees and the satisfaction of colleagues according to the majority of USK Medical Faculty employees are factors that are considered in building good knowledge management. Furthermore, the calculation of composite reliability and AVE gives values of 0.887 and 0.569 , respectively, which can be concluded that all items are not only valid but also reliable in measuring knowledge management. The composite reliability value of 0.887 states that $88.7 \%$ of employees' assessment of knowledge management can be reflected in the employee's answers to the six items used to measure this variable. While the AVE of 0.569 stated that $56.9 \%$ of the variation in employee answers to the six items was influenced by their understanding of knowledge management. The higher the composite reliability and AVE values, the more reliable these six items are in measuring knowledge management variables variable.

Job Satisfaction Variable

The job satisfaction variable is measured by five indicators with the following path diagrams: 


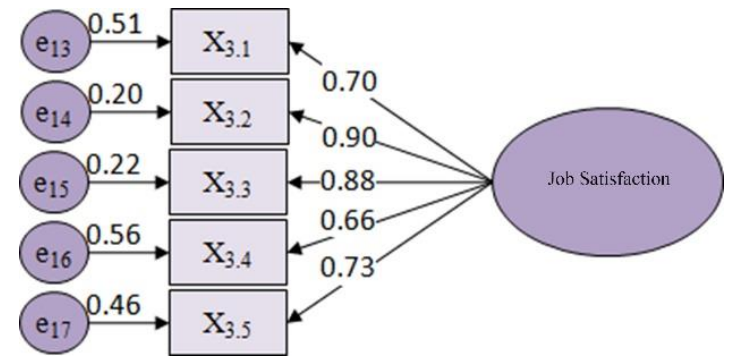

Figure 4. Path Diagram of the Job Satisfaction Variable

Table 5. Validity and Reliability of Job Satisfaction Variable

\begin{tabular}{|l|c|c|c|c|c|}
\hline \multicolumn{2}{|c|}{ Indicator } & $\begin{array}{c}\text { Validity } \\
\text { Coefficient }\end{array}$ & R2 & $\begin{array}{c}\text { Error } \\
\text { Variance }\end{array}$ & $\begin{array}{c}\mathrm{t}- \\
\text { count }\end{array}$ \\
\hline Satisfied with compensation & $\mathrm{X} 3.1$ & 0.700 & 0.490 & 0.510 & - \\
\hline Fair promotion & $\mathrm{X} 3.2$ & 0.900 & 0.810 & 0.190 & 10.08 \\
\hline Fun teamwork d & $\mathrm{X} 3.3$ & 0.880 & 0.774 & 0.226 & 9.97 \\
\hline Leaders supervise & $\mathrm{X} 3.4$ & 0.660 & 0.436 & 0.564 & 7.67 \\
\hline $\begin{array}{l}\text { The work gets an award from the } \\
\text { leadership }\end{array}$ & $\mathrm{X} 3.5$ & 0.730 & 0.533 & 0.467 & 8.46 \\
\hline Composite Reliability & & & \multicolumn{5}{|c|}{0.884} \\
\hline Average Variance Extracted & & & & \\
\hline
\end{tabular}

The results of the analysis for the job satisfaction variable measurement model found that the item had a loading factor or validity coefficient greater than 0.600 with a $\mathrm{t}$-count value greater than 1.65. These results indicate that all items are valid and significant in measuring the job satisfaction variable. The most priority or important item in measuring the job satisfaction variable is a fair promotion item with a loading factor of 0.900 . This can be interpreted that the existence of fair promotion from the leadership according to the majority of USK Medical Faculty employees is a factor that is considered in building high job satisfaction. Furthermore, the calculation of composite reliability and AVE gives a value of 0.884 and 0.609 , respectively, which can be concluded that all items are not only valid but also reliable in measuring job satisfaction. The composite reliability value of 0.884 states that $88.4 \%$ of the employee's assessment of job satisfaction can be reflected in the employee's answers to the five items used to measure this variable. While the AVE of 0.609 states that $60.9 \%$ of the variation in employee answers to the five items is influenced by their understanding of job satisfaction. The higher the composite reliability and AVE values, the more reliable these five items are in measuring the job satisfaction variable.

\section{Organizational Commitment Variable}

The commitment variable is measured by four indicators with the path diagrams presented as follows: 


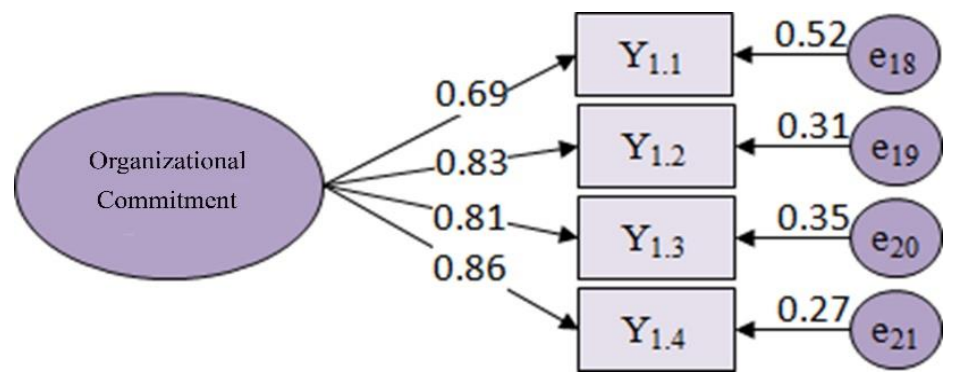

Figure 5. Path Diagram of Organizational Commitment Variable

Table 6. Validity and Reliability of Organizational Commitment Variable

\begin{tabular}{|l|c|c|c|c|c|}
\hline \multicolumn{2}{|c|}{ Indicator } & \multicolumn{1}{c|}{$\begin{array}{c}\text { Validity } \\
\text { Coefficien } \\
\mathrm{t}\end{array}$} & $\mathrm{R} 2$ & $\begin{array}{c}\text { Error } \\
\text { Variance }\end{array}$ & t-count \\
\hline Dedication gets an award from the leadership & $\mathrm{Y} 1.1$ & 0.690 & 0.476 & 0.524 & - \\
\hline Improve the performance set by the leadership & $\mathrm{Y} 1.2$ & 0.830 & 0.689 & 0.311 & 9.22 \\
\hline $\begin{array}{l}\text { Have a high willingness to carry out the } \\
\text { leadership's orders }\end{array}$ & $\mathrm{Y} 1.3$ & 0.810 & 0.656 & 0.344 & 9.02 \\
\hline Work targets can be achieved well & $\mathrm{Y} 1.4$ & 0.860 & 0.740 & 0.260 & 9.49 \\
\hline Composite Reliability & & & \multicolumn{5}{|c|}{0.876} \\
\hline Average Variance Extracted & & \multicolumn{4}{|c}{0.640} \\
\hline
\end{tabular}

The results of the analysis for the organizational commitment variable measurement model found that the item had a loading factor or validity coefficient greater than 0.600 with a $\mathrm{t}$-count value greater than 1.65. These results indicate that all items are valid and significant in measuring the organizational commitment variable. The most priority or important item in measuring the organizational commitment variable is the work target item that can be achieved well with a loading factor of 0.900 . This can be interpreted that the ability to achieve work targets well according to the majority of USK Medical Faculty employees is a factor that is considered in building high organizational commitment. Furthermore, the calculation of composite reliability and AVE gives a value of 0.876 and 0.640 , respectively, which can be concluded that all items are not only valid but also reliable in measuring organizational commitment. The composite reliability value of 0.876 states that $87.6 \%$ of the employee's assessment of organizational commitment can be reflected in the employee's answers to the four items used to measure this variable. While the AVE of 0.640 states that $64.0 \%$ of the variation in employee answers to the four items is influenced by their understanding of organizational commitment. The higher the composite reliability and AVE values, the more reliable these four items are in measuring organizational commitment variables variable.

Employee Performance Variable

Employee performance variables are measured by five indicators with the following path diagrams: 


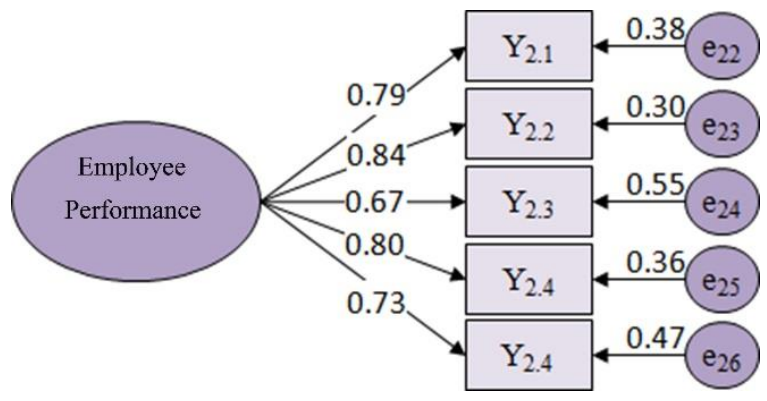

Figure 6. Path Diagram of Employee Performance Variable

Table 7. Validity and Reliability of Employee Performance Variable

\begin{tabular}{|c|c|c|c|c|c|}
\hline \multicolumn{2}{|l|}{ Indicator } & $\begin{array}{l}\text { Validity } \\
\text { Coefficient }\end{array}$ & $\mathrm{R} 2$ & $\begin{array}{l}\text { Error } \\
\text { Varianc } \\
\text { e }\end{array}$ & $\begin{array}{c}\mathrm{t}- \\
\text { count }\end{array}$ \\
\hline Demonstrate loyalty to the organization & Y2.1 & 0.790 & 0.624 & 0.376 & - \\
\hline $\begin{array}{l}\text { Work performance gets an award from } \\
\text { the leadership }\end{array}$ & Y2.2 & 0.840 & 0.706 & 0.294 & 11.02 \\
\hline Responsibilities can be carried out & Y2.3 & 0.670 & 0.449 & 0.551 & 8.95 \\
\hline Obey every rule & Y2.4 & 0.800 & 0.640 & 0.360 & 10.43 \\
\hline $\begin{array}{l}\text { Able to show honesty in every work } \\
\text { program }\end{array}$ & $\mathrm{Y} 2.5$ & 0.730 & 0.533 & 0.467 & 9.40 \\
\hline Composite Reliability & & & & & \\
\hline Average Variance Extracted & & & 0. & & \\
\hline
\end{tabular}

The results of the analysis for the employee performance variable measurement model found that the item had a loading factor or validity coefficient greater than 0.600 with a t-count value greater than 1.65. These results indicate that all items are valid and significant in measuring employee performance variables. The most priority or important item in measuring employee performance variables is the work achievement item getting an award from the leadership with a loading factor of 0.840 . This can be interpreted that the appreciation of work performance from the leadership according to the majority of USK Medical Faculty employees is a factor that is considered in building high employee performance. Furthermore, the calculation of composite reliability and AVE gives a value of 0.877 and 0.590 , respectively, which can be concluded that all items are not only valid but also reliable in measuring employee performance. The composite reliability value of 0.877 states that $87.7 \%$ of employee evaluations of employee performance can be reflected in the employee's answers to the five items used to measure this variable. While the AVE of 0.590 states that $59.0 \%$ of the variation in employee answers to the five items is influenced by their understanding of employee performance. The higher the composite reliability and AVE values, the more reliable these five items are in measuring employee performance variables. 


\section{Testing the Structural Model (H2 to H11)}

The results of direct effect hypothesis testing as determined in this research can be seen as follows.

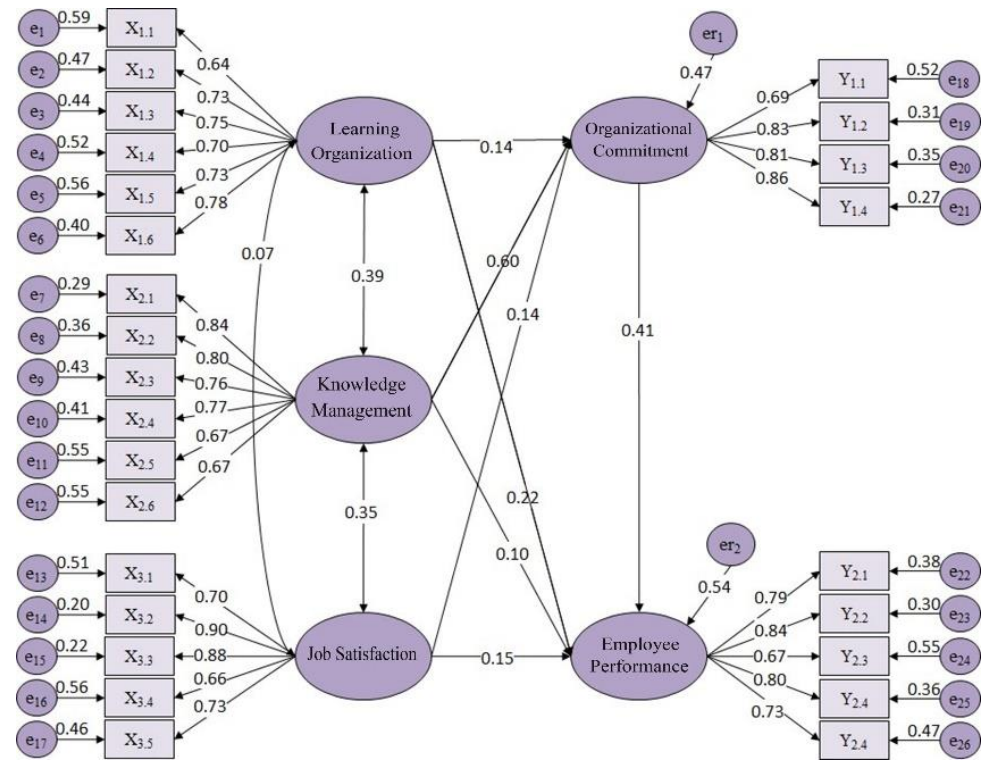

Figure 8. Full SEM Model

This path diagram describes the two sub-structures of the model, namely:

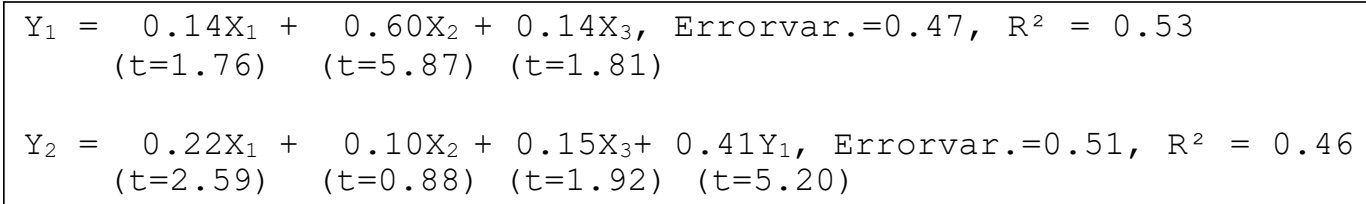

The first model is a model that explains the influence of learning organizations (X1), knowledge management (X2), job satisfaction (X3) on organizational commitment (Y1). While the second sub-structure of the model explains the influence of learning organizations (X1), knowledge management (X2), job satisfaction (X3), and organizational commitment (Y1) on employee performance (Y2) USK Medical Faculty.

\section{$\underline{\text { First Sub-Structure }}$}




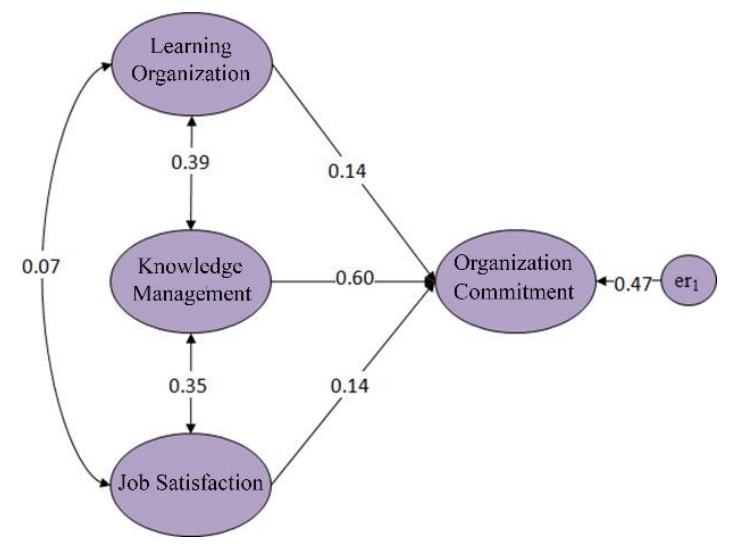

Figure 9. First Sub-Structure Path Diagram

The results of the analysis show that the knowledge management variable is the most dominant variable influencing changes in employee commitment with a large effect reaching 0.60 standard deviations. While the variables with the second and third largest influence have the same value, namely 0.14 standard deviation. The variables are learning organization and employee job satisfaction. The results of the analysis for the first sub-model provide a coefficient of determination of 0.53 which indicates that $53 \%$ of the diversity of the employee commitment variables is explained by the learning organization variables, knowledge management, and employee satisfaction with knowledge management variables being the most dominant variable.

Furthermore, to prove whether the effect is significant, hypothesis testing is carried out as follows:

Table 8. Results of the First Sub-Structure Hypothesis Testing

\begin{tabular}{|l|c|c|c|l|}
\hline \multicolumn{1}{|c|}{ Variable } & Effect & t-count & t-table & \multicolumn{1}{c|}{ Decision } \\
\hline Learning Organization & 0.140 & 1.76 & 1.655 & H0 rejected \\
\hline Knowledge Management & 0.600 & 5.87 & 1.655 & H0 rejected \\
\hline Job satisfaction & 0.140 & 1.81 & 1.655 & H0 rejected \\
\hline
\end{tabular}

The results of hypothesis testing using student t-test statistics obtained all null hypotheses are rejected with the conclusion that there is a positive and significant influence from the learning organization, knowledge management and job satisfaction on employee work commitment.

\section{$\underline{\text { Second Sub-Structure }}$}




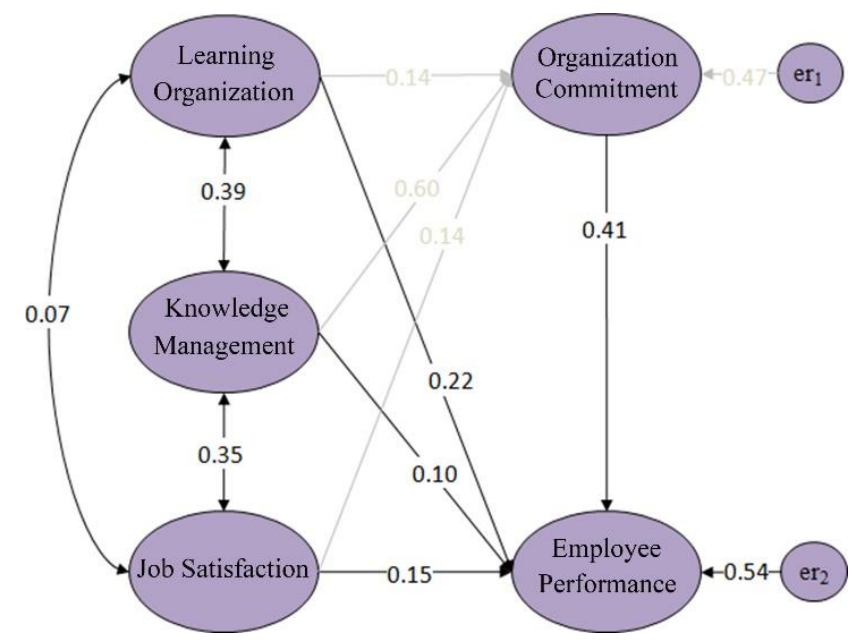

Figure 10. Second Sub-Structure Path Diagram

The employee performance variable is most dominantly influenced by the employee commitment variable with a large influence reaching 0.41 standard deviation, then the next is the learning organization variable with a large influence of 0.22 standard deviation. Knowledge management variable gives the lowest effect with a large effect of only 0.10 standard deviation while the effect of job satisfaction on employee performance is relatively larger, namely 0.15 standard deviation. Meanwhile, the coefficient of determination of the second sub-structure of the model is 0.46 which shows that $46 \%$ of the diversity of the employee performance variables is explained by the learning organization variables, knowledge management, employee satisfaction and employee work commitment with employee work commitment being the most dominant variable.

Tabel 9. Results of the Second Sub-Structure Hypothesis Testing

\begin{tabular}{|l|c|c|c|l|}
\hline \multicolumn{1}{|c|}{ Variable } & Effect & t-count & t-table & \multicolumn{1}{c|}{ Decision } \\
\hline Learning Organization & 0.220 & 2.59 & 1.655 & H0 rejected \\
\hline Knowledge Management & 0.100 & 0.88 & 1.655 & H0 Accepted \\
\hline Job satisfaction & 0.150 & 1.92 & 1.655 & H0 rejected \\
\hline Organizational Commitment & 0.410 & 3.27 & 1.655 & H0 rejected \\
\hline
\end{tabular}

The results of hypothesis testing for the second sub-structure found that only the knowledge management variable does not affect employee performance, while the learning organization variables, job satisfaction, and organizational commitment had a significant positive effect. Furthermore, an analysis is carried out to determine whether the organizational commitment is a significant mediating variable to encourage employee performance improvement. 


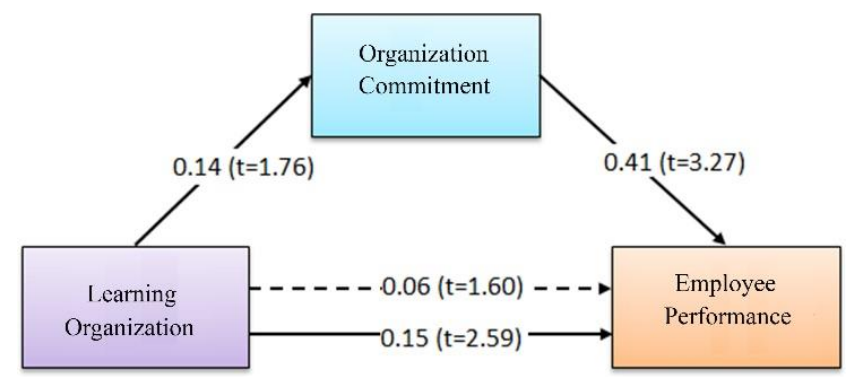

\section{Figure 11. Analysis of the Mediating Effect of Hypothesis 9}

The results of the analysis found that the indirect effect of learning organizations on employee performance through employee work commitment was 0.06 standard deviation with a $t$ value of 1.60. This value is smaller than 1.65 so it can be concluded that the indirect effect is not significant which can be interpreted that the organizational commitment variable is not a mediating variable for the learning organization variable so that it can affect employee performance.

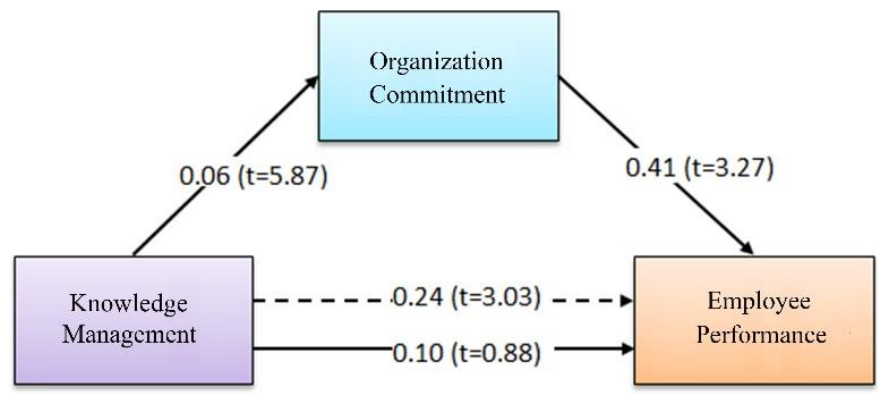

Figure 12. Analysis of the Mediating Effect of Hypothesis 10

The results of the analysis found an indirect effect of knowledge management on employee performance through employee work commitment of 0.24 standard deviation with a $\mathrm{t}$ value of 3.03. This value is greater than 1.65 so it can be concluded that the indirect effect is significant which can be interpreted that the organizational commitment variable is a full mediating variable for the knowledge management variable. This means that knowledge management will be able to improve employee performance if it is supported by a strong organizational commitment.

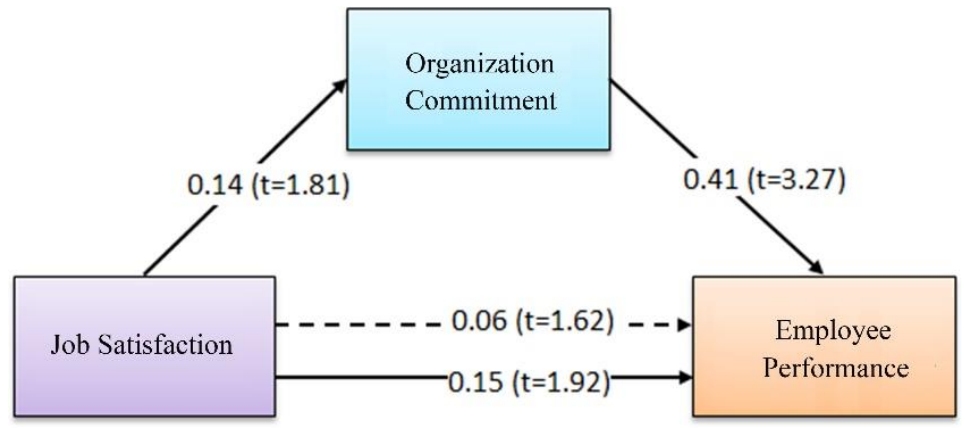

Figure 13. Analysis of the Mediating Effect of Hypothesis 11 
The results of the analysis found an indirect effect of job satisfaction on employee performance through employee work commitment of 0.06 standard deviation with a $t$ value of 1.60. This value is smaller than 1.65 so it can be concluded that the indirect effect is not significant which can be interpreted that the organizational commitment variable is not a mediating variable for the variable job satisfaction to employee performance.

\section{Conclusion}

The test results prove that the direct effect testing process proves that there is an effect of organizational learning, knowledge management, and job satisfaction on organizational commitment. In addition, learning organization, job satisfaction, and organizational commitment significantly affect the performance of USK Medical Faculty employees, while knowledge management does not significantly affect USK Medical Faculty employee performance. Furthermore, the results of the indirect effect testing process prove that organizational commitment acts as a full mediator in mediating the influence of knowledge management on the performance of USK Medical Faculty employees, while organizational commitment does not significantly act as a mediator between learning organizational variables and job satisfaction to affect the USK Medical Faculty employee performance.

The interesting thing is it turns out that the model for improving employee performance at USK Medical Faculty depends on the direct influence of learning organizations, job satisfaction, and work commitment. Work commitment turned out to play a role as a full mediation between increasing knowledge management to stimulate an increase in the performance of USK Medical Faculty employees. This finding contributes to the strengthening of the employee performance model academically, especially in a campus environment such as the USK Medical Faculty. For future researchers, they can use this tested model as a basis for the development of further research models, by adding other variables such as organizational citizenship behavior and talent management. For practitioners, especially leaders at USK Medical Faculty can take advantage of this research model in improving the performance of their employees so as to achieve superior performance.

\section{References}

1) Arifah, D. A., \& Romadhon, C. (2015). Pengaruh Komitmen Organisasi, Komitmen Profesional dan Gaya Kepemimpinan terhadap Kepuasaan Kerja dengan Motivasi sebagai Variabel Intervening. Conference In Business, Accounting, And Management (CBAM), 2(1), 357-369.

2) Baron, R. M., \& Kenny, D. A. (1986). The moderator-mediator variable distinction in social psychological research: Conceptual, strategic, and statistical considerations. Journal of Personality and Social Psychology, 51(6), 1173-1182. 
243 | International Journal of Scientific and Management Research 4(5) 225-244

https://doi.org/10.1037//0022-3514.51.6.1173

3) Basten, D., \& Haamann, T. (2018). Approaches for Organizational Learning: A Literature Review. SAGE Open - Literature Review, 1-28. https://doi.org/10.1177/2158244018794224

4) Bernardin, H. J., \& Russell, J. E. A. (2012). Human Resource Management (6th ed.). New York: McGraw-Hill.

5) Davidson, C., \& Voss, P. (2002). Knowledge Management: An Introduction to Creating Competitive Advantage from Intellectual Capital. USA: Tandem Press.

6) Engko, C. (2008). Pengaruh Kepuasan Kerja Terhadap Kinerja Individual Dengan Self Esteem dan Self Efficacy Sebagai Variabel Intervening. Jurnal Bisnis Dan Akuntans, 10(1).

7) Furnham, A., Petrides, K. V., Jackson, C. J., \& Cotter, T. (2002). Do personality factors predict job satisfaction? Personality and Individual Differences, 33(8), 1325-1342. https://doi.org/10.1016/S0191-8869(02)00016-8

8) Gephart, M. A., Marsick, V. J., Van Buren, M. E., Spiro, M. S., \& Senge, P. (1996). Learning Organizations Come Alive. Training \& Development. Retrieved from https://www.questia.com/magazine/1G1-19045456/learning-organizations-come-alive

9) Greenberg, J., \& Baron, R. A. (2018). Behavior in Organizations: Understanding and Managing the Human Side of Work (Ed. 8). New Jersey: Prentice Hall.

10) Hernaus, T., Bach, M. P., \& Vuksic, V. B. (2012). Influence of strategic approach to BPM on financial and non-financial performance. Baltic Journal of Management, 7(4), 376-396. https://doi.org/10.1108/17465261211272148

11) Jønsson, T., Jain, A. K., \& Jeppesen, H. J. (2013). The employees' participation in leadership tasks during organizational restructuring: The case of a hospital merger. The 16th Congress of the European Association of Work and Organizational Psychology. Münster, Germany: School Of Business And Social Sciences Aarhus University.

12) Koh, H. C., \& Boo, E. H. Y. (2001). The Link Between Organizational Ethics And Employee Job Satisfaction; A Study Of Managers In Singapore. Journal of Business Ethics, 29(4), 309-324. https://doi.org/10.1023/A:1010741519818

13) Matayong, S., \& Mahmood, A. K. (2013). The review of approaches to knowledge management system studies. Journal of Knowledge Management, 17(3), 472-490. https://doi.org/10.1108/JKM-10-2012-0316

14) Mathis, R. L., \& Jackson, J. H. (2019). Human Resource Management: Personnel Human Resource Management (Ed. 15). USA: Harvard Business Review.

15) Mowday, R. T., Porter, L. W., \& Steers, R. M. (2013). Employee-organization linkages: The psychology of commitment, absenteeism, and turnover. Retrieved from https://books.google.co.id/books?hl=en\&lr=\&id=f_FFBQAAQBAJ\&oi=fnd\&pg=PP1\&d $\mathrm{q}=$ The+Psychology+of+Commitment,+Absenteeism,+and+Turnover\&ots=GjRzL7Mg_3 \&sig=Rr9BvXL6mJBF4VJc8x9PBPay6ZY\&redir_esc $=y \# v=$ onepage $\& q=T h e$ Psychology of Commitment\%2C Absenteeism\%2C and T 
16) Munandar, A. S. (2001). Psikologi Industri Dan Organisasi. Jakarta: Universitas Indonesia.

17) Pérez López, S., Manuel Montes Peón, J., \& José Vazquez Ordás, C. (2005). Organizational learning as a determining factor in business performance. The Learning Organization, 12(3), 227-245.

18) Ramírez, A. M., García-Morales, V. J., Morales, G., \& Martín-Rojas, R. (2007). Knowledge Creation, Organizational Learning and Their Effects on Organizational Performance. Engineering Economics, 22(3), 309-318. https://doi.org/10.5755/j01.ee.22.3.521

19) Respatiningsih, I., \& Sudirjo, F. (2015). Pengaruh Komitmen Organisasi, Motivasi, Kapabilitas dan Kepuasaan Kerja Terhadap Kinerja Pegawai (Studi Empirik pada Inspektorat Kabupaten Pemalang. Serat Acitya (Jurnal Ilmiah), 4(3), 56-58.

20) Senge, P. M. (1990). The art and practice of the learning organization. Retrieved from http://kmcenter.rid.go.th

21) Sopiah, \& Sangadji, E. M. (2018). Manajemen Sumber Daya Manusia Strategik. Yogyakarta: Andi Publisher.

22) Sutrisno, E. (2019). Budaya Organisasi. Jakarta: Prenada Media.

23) Tranggono, R. P., \& Kartika, A. (2008). Pengaruh Komitmen Organisasional dan Profesional terhadap Kepuasan Kerja Auditor dengan Motivasi sebagai Variabel Intervening. Jurnal Bisnis Dan Ekonomi, 15(1), 80-90.

24) Waterkamp, C. I. A., Tawas, H. N., \& Mintardjo, C. . (2017). Pengaruh Profesionalisme, Komitmen Organisasi dan Kepuasan Kerja terhadap Kinerja Karyawan pada PT. Bank Rakyat Indonesia (PERSERO) Cabang Manado. Jurnal Emba, 5(3), 2808-2818. https://doi.org/https://doi.org/10.35794/emba.v5i3.17159 